

\section{What Explains Agency Heads' Length of Tenure? Testing Managerial \\ Background, Performance, and Political Environment Effects}

Nicolai Petrovsky*

(University of Kentucky)

Email: nicolai.petrovsky@uky.edu

435 Patterson Office Tower

Martin School, University of Kentucky

Lexington KY 40506-0027

U.S.A.

Oliver James

(University of Exeter)

Email: o.james@exeter.ac.uk

Department of Politics

Amory Building

Rennes Drive

Exeter, Devon

EX4 4RJ

United Kingdom

Alice Moseley

(University of Exeter) 
Email: a.moseley@exeter.ac.uk

Department of Politics

Amory Building

Rennes Drive

Exeter, Devon

EX4 4RJ

United Kingdom

George A. Boyne

(Cardiff University)

Email: boyne@cardiff.ac.uk

Pro Vice-Chancellor, College of Arts, Humanities \& Social Sciences

Cardiff University

Cardiff, Wales

CF10 3AT

United Kingdom

* Corresponding author 


\section{Author biographies}

Nicolai Petrovsky is an associate professor in the Martin School of Public Policy \& Administration at the University of Kentucky. His research interests include government performance, managerial succession, and citizen interactions with public services. He has done extensive work on these topics in two collaborative projects on English local government and British central government. E-mail: nicolai.petrovsky@uky.edu

Oliver James is professor of political science at the University of Exeter, United Kingdom. He works on the public policy and politics of public services, citizen-provider relationships, public sector organization and reform, executive politics (particularly politician-administrator relations), and regulation of publicly owned and/or funded bodies and services. He also works on methodology for using experiments in public management research. E-mail:

o.james@exeter.ac.uk

Alice Moseley is a Lecturer (Education and Research) in the Department of Politics at the University of Exeter, United Kingdom. Her research is broadly concerned with understanding citizens' interactions with the state, including co-production and participation in public services, and civic/ political engagement more broadly. She also has interests in the application of behavioral economics to public policy. Much of her recent work makes use of experimental methods, especially field experiments. E-mail: a.moseley@exeter.ac.uk 
George Boyne is professor of public management at Cardiff University, United Kingdom. His main research interest is organizational performance in the public sector. He is currently working on topics that include executive succession and administrative intensity. E-mail:

boyne@ cardiff.ac.uk 


\section{Practitioner points}

We analyzed the length of tenure of the heads of British central government executive agencies. This type of organization, first established in 1989, involves a high degree of autonomy for agency heads.

For our study, we built a database of these officials and the organizations they led, ranging from the first agencies in 1989 until 2012.

Heads of agencies that perform poorly relative to other agencies tend to retire somewhat sooner than others, and well before the usual retirement age. This is consistent with the policy behind the executive agency organizational model as 'performance based organizations.'

Regardless of actual performance consequences, stakeholders may demand symbolic managerial turnover. A flexible personnel system like the British one for senior public managers is aligned with such demands.

Agency heads recruited from outside central government are relatively difficult to retain for a longer time. If there is a wave of retirements of senior career civil servants, it is a risky strategy to expect replacing them with lateral recruitments from other levels of government and the private sector. 


\begin{abstract}
There are a number of influences on how long an agency head serves. The importance of particular influences in turn depends on the prospective destination of the agency head:

elsewhere in the public sector; the private sector; or retirement. We estimate survival models of agency heads' tenure using panel data on British central government executive agencies from 1989-2012. Our findings suggest that chief executives of poorly performing agencies are encouraged to retire sooner. We find no evidence of change in political control increasing risk of any form of exit, suggesting that political pressure to leave is not substantial for this type of official. Outsiders (agency heads recruited from outside central government) are relatively difficult to retain for a longer time, such that potential shortfalls in suitable managers caused by retirements in an aging workforce may be difficult to make up by appointing from this source.
\end{abstract}




\section{What Explains Agency Heads' Length of Tenure? Testing Managerial Background, Performance, and Political Environment Effects}

A major issue in public service management is how long agency heads serve. Length of tenure has important implications because if agency heads serve only a short time, they may not be able to contribute effectively to the organization they lead (Hess 1998) or may be part of more general turnover that damages performance (Bertelli and Lewis 2013). In contrast, if they stay too long, their leadership may stagnate and not keep pace with changes in the organizational environment (Miller 1991). Theory suggests that there are certain personal, organizational, and environmental characteristics that predict the time that senior managers will serve before leaving. However, existing empirical research on public sector executives has focused on organizational factors, especially prior performance and political change (Whitaker and DeHoog 1991; Hood and Lodge 2006; McCabe et al 2007; Boyne et al. 2010a; 2010b). We lack knowledge about the relevance of personal characteristics such as previous work experience, in contrast to the large amount of research on this issue in the private sector (Hambrick and Mason 1984; Fredrickson et al. 1998; Karaevli 2007; Finkelstein et al. 2009). The main exception has been recent work looking at factors affecting intention to exit of public servants (Bertelli and Lewis 2013; Whitford and Lee 2014). This work on turnover intention has considerable relevance to understanding agency heads' tenure but it is also important to look at actual turnover.

Still, relatively little is known about realized turnover at the managerial level. In their synthesis of research on realized public employee turnover, Grissom et al. (2016) identify three insights that are also of relevance to managerial turnover. First, it is difficult to distinguish empirically between forced and voluntary departures (243). Second, empirical studies should 
distinguish between exits to other positions in the same field ("mobility") and exits to other positions ("attrition") because the two are often predicted by different factors (243). Finally, the linkage between organizational performance and turnover merits further study (247). We build on these insights with our study. First, we examine all cases where an agency head ends their period of tenure in charge of an organisation. Second, we examine variations in the length of tenure of agency heads depending on the type of exit (especially, whether they stay in the public sector or leave it). Finally, we include organizational performance as a variable in the theoretical argument and test for its influence on agency head tenure using a cross-agency indicator. Our research questions are: Which personal and organizational factors explain the actual length of tenure of agency heads? How do the predictors of length of tenure affect the incidence of exits to different destinations?

The first section of this article sets out the theory and existing evidence about factors affecting the tenure of agency heads. Based on this body of work, we develop hypotheses about how public sector experience of agency heads, agency performance, and political change determine agency heads' length of tenure. We expand upon these hypotheses to also address the incidence of the different exits.

The second section sets out our method, which departs from most previous work on tenure in recognizing that predictors of exit do not only affect length of tenure but also the incidence of different types of exit. We contrast an aggregated survival model for all exits with competing risk survival models that recognize that tenure is at risk of ending in different ways. We use a dataset of heads of executive agencies, who are called agency chief executives in Britain, to examine the relationship between personal and organizational variables on the one 
hand and their actual length of tenure and type of exit on the other, for British central government in the period from 1989 to 2012.

The third section reports our results. After a review of the limitations of our study in the fourth section, in the final section we draw conclusions and implications for public management in general and especially for executive agencies. The implications have broad relevance because this form of performance-based organization is found not only in British central government but also in other parliamentary systems, notably in Austria, Australia, Belgium, Canada, Denmark, Estonia, Germany, Hungary, Ireland, Italy, Netherlands, Norway, and Sweden (James 2003; Pollitt and Talbot 2004; James and Van Thiel 2010; Verhoest et al. 2012). 


\section{Agency heads' length of tenure}

We are interested in systematic variation in the length of tenure of heads of government agencies in settings with merit protections for such positions. The theoretical argument has to be somewhat different from settings where agency heads serve at the pleasure of elected officials, as is the case in presidential systems across the Americas. We suggest there are systematic factors related to whether an agency head continues to serve for another year or leaves. We organize these factors in a framework used by Grissom and Andersen (2012) in their model of U.S. school district superintendent turnover.

The major difference to Grissom and Andersen's (2012) framework (and to studies of U.S. city manager turnover) lies in the absence of outright dismissals of agency heads - even the most publicized case of a dismissal (Derek Lewis of the Prison Service in 1995) resulted in a settlement in the following year, recognizing that the dismissal was wrongful. Agency head contracts can be terminated for low performance but not explicitly because of political change. Generally, agency heads weigh the options available to them and choose the one that is most attractive on balance. Staying for another year is one option; the other options all involve exiting the agency. The availability of the option to leave greatly affects intention and behavior (Hirschman 1970; Dowding and John 2012; Bertelli and Lewis 2013). Public managers who are able to associate themselves with success in an organization are able to use it to enhance their careers by moving on to other organizations (Hess 1998; Teodoro 2011).

As Grissom and Andersen (2012) point out very clearly when discussing approaches to researching this topic area, researchers cannot directly observe the decision calculus of the managers who choose whether or not to stay for another year (1152). All we observe are 
systematic factors going into the decision calculus, and the final outcome: to stay or to go. We conceptualize these factors as belonging to three levels of analysis: individual, organizational, and environmental. Our perspective is general to domains of agency heads running organizations that have a focus on the performance of public activity overseen by politicians in parliamentary systems and who also have some formal protection of tenure from operating in merit systems. In this article we develop hypotheses which we then assess in the domain of British central government.

We begin with the individual level. The theoretically most interesting individual characteristic covers agency heads' sector-specific expertise and socialization stemming from prior managerial experience, after all, this is a key rationale for researchers focusing on public management as opposed simply to generic management. We focus specifically on whether an agency head is an insider to the public sector based on prior work experience. Our approach draws on the concept of managerial insiderness as used within the 'upper echelon' private sector management literature (Hambrick and Mason 1984; Karaevli 2007; Finkelstein et al. 2009). There, insiderness is defined as the degree to which a top manager's prior firm or industry managerial experience resembles characteristics of the organization they currently manage (Hambrick and Mason 1984; Zhang and Rajagopalan 2004; Karaevli 2007; Finkelstein et al. 2009).

The public sector is distinctive in several ways. While the focus is often on public ownership, organizations both in the public and private sectors also vary greatly in the extent they are funded through appropriations and regulated by government agencies (Petrovsky et al. 2015). We suggest that experience on the more public side of all three dimensions lets agency heads reap the benefits of greater fit with the requirements of their posts. Public ownership 
implies distinct requirements of accountability and restrictions on personnel and resource use. Public funding for any organization, public or private, also tends to bring enhanced accountability requirements with it. The degree of public regulation refers to the degree to which elected officials or their agents use public authority to constrain the policies and practices of an organization with rules and standards (Hood, James, and Scott 2000; Hood et al. 1999; James 2000).

Insiders (agency heads with prior public sector experience) can be expected to both be better at managing in this context and have sector-specific skills and experience, which should lead them to stay longer including by being able better to avoid or resist pressures to exit, other things being equal. This idea is consistent with Bertelli and Lewis's (2013) finding that the more senior executives in U.S. federal agencies invest in agency specific knowledge and expertise, the lower is their intention to exit that agency (Bertelli and Lewis 2013). Conversely, outsiders to the public sector will, often enough, find the challenge to reward ratio in the public sector to be higher than what they are used to (and higher than they expected). Also, their skills, experience, and connections outside of the public sector provide them with potential exit options. We therefore expect agency heads who are public sector outsiders to exit their posts sooner than insiders. In the context of this article, we consider insiders as being insiders to British central government working in organizations reporting to ministers, which is a distinctive sector of public employment with associated status, networks of contacts and shared experience.

Hypothesis 1: Insiders to British central government will have a lower risk of exit (i.e. a longer tenure) than non-insiders. We expect this relationship to hold across exit types.

Next, we consider the organizational level. The head of an agency, formally called the chief executive in many contexts (including the executive agencies in Britain that we analyze 
empirically), stands out from the team of senior managers running an organization by being formally in overall control of the organization (Mintzberg 1975; Norburn 1989). For this reason, the agency head is frequently held responsible for the course of the organization (Furtado and Karan 1990; Van Wart 2003; Boyne et al. 2010b). Organizational performance therefore has to be part of a theory of agency head length of tenure. It is widely recognized that performance tends to be harder to measure in the public sector relative to the private sector, where profit and share prices provide somewhat clearer metrics. What counts as performance is often disputed in public organizations (Behn 2003; Heinrich 2003; Radin 2006; Moynihan 2008). At the same time, for agency heads interested in staying in their role, an important aspect of performance is whatever those overseeing him or her say it is. Poor performance does drive the exit of managers in the public sector where strong metrics used by overseers exist. Research has found that the poorest level of performance relative to higher level performance drives exit rather than a linear relationship between increasing performance and longer tenure (Boyne et al. 2010b).

Performance could be assessed at the individual level of the agency head, or at the level of the agency they formally lead. Unlike for positions lower down the hierarchy, the two aspects of performance are closely linked for agency heads, partly for symbolic reasons. That is, even a talented and hard-working agency head is not normally considered to perform well if the agency they preside over is performing poorly, albeit for factors outside of the agency head's control. In the British context, agency head contracts have been explicitly tied to agency performance as part of the underlying philosophy of the Next Steps reforms (Cabinet Office 2006, 18).

There are two countervailing forces affecting the length of tenure of agency heads overseeing organizational performance that is deemed low by their overseers. On the one hand, low organizational performance is a reason to not renew an agency head's contract even in 
settings with merit protections such as ours. On the other hand, being associated with low organizational performance reduces an agency head's outside options. As the second force is not relevant to agency heads considering retirement, and there is some flexibility about the age at which retirement occurs, we expect this group to retire sooner than agency heads overseeing organizational performance that is deemed adequate or better by their overseers. Expressed as a hypothesis, this becomes:

Hypothesis 2a: Agency heads overseeing low performance and continuing their career will not differ in their risk of exit (i.e. a shorter tenure) from other agency heads. However, agency heads headed for retirement will retire sooner if they oversee low performance than agency heads who oversee higher levels of performance.

The presence of attractive exit options leads us to suggest that high organizational performance will shorten the tenure of agency heads. In settings with caps on the compensation that can be paid to senior managers (which includes the British agencies we study), high performance that makes someone attractive to other employers leads to more rewards outside the agency. This is not the case for retirement, because the value of the pension option is not linked to rewards from alternative employers in the same way if an agency head exits at a high point. Expressed as a hypothesis, this becomes:

Hypothesis 2b: Agency heads overseeing high performance will have a higher risk of exit (i.e. a shorter tenure) than other agency heads. We expect this relationship not to hold for agency heads exiting into retirements.

The third and final level of expected determinants of agency head tenure is the political environment. Our focus is on systems without formal political appointees, which have received less attention than systems with layers of political appointments, notably the U.S. system (Lewis 
1991; Lewis 2007). In the context of national government, there are two types of political change: change in the party in charge of government and change in the minister overseeing a particular agency. Either type of political change brings disruption and, often, a change in emphasis. This change may lead to subsequent managerial changes either for substantive or symbolic reasons. The degree to which the preferences of agency heads and their elected overseers overlap is likely an important influence on the ease of their interaction (Whitaker and DeHoog 1991; Boyne et al. 2010a). Congruence in political preferences between elected officials and top managers is unobservable in many contexts because of the lack of measures of top managerial preferences outside of the U.S. federal government, where Clinton et al. (2012) provide estimates.[LINK TO ENDNOTE 1]

An alternative approach is provided by considering the implications of a change in political overseers, a topic that has been examined in work on political appointees in the U.S. (Wood and Waterman 1994; Lewis 2007; Wood and Marchbanks 2008) and several European democracies (Kopecký, Mair and Spirova 2012). There is an expectation that new elected officials will often replace appointed officials who are associated with the previous political regime. Research has found that party political influences on tenure of chief executives are not confined to systems with formal political appointees; through indirect mechanisms it can occur in systems with merit protections and no chief executive political appointees. In English local government, change in party control was followed by more departures from senior management teams and, when combined with poor service performance, also more exits of chief executives (Boyne et al. 2010a). Generalizing from these findings to the context of central government, we expect that political change, in both political party and minister overseeing the public 
organization, should be associated with shorter chief executive tenure, as expressed in the following hypothesis:

Hypothesis 3: Agency heads serving during a political change will have a higher risk of exit (i.e. a shorter tenure). We expect this relationship to hold across exit types.

\section{Data and methods}

We analyze the tenure of 247 chief executives of 129 executive agencies in British central government using a panel dataset covering the years 1989-2012.[LINK TO ENDNOTE 2] This setting provides a good opportunity to examine how differences in chief executive insider background, performance, and political changes relate to chief executives' tenure. The context is of broad relevance because the executive agency model is widespread across parliamentary systems in many countries around the world (James 2003; Pollitt and Talbot 2004; James and Van Thiel 2010; Verhoest et al 2011). In this model, organizational performance and chief executive tenure are linked because the position of the post-holder is not permanent and organizational performance is an important aspect of the assessment of how well the individual post-holder is doing his or her job and whether they should continue. In the U.S., the Clinton-era National Performance Review proposed similar Performance-Based Organizations (PBO) but this idea was never fully implemented, as it would have violated both Congress's supremacy over appropriations and the President's authority to remove agency heads if they lose his or her confidence (Hill and Lynn 2009).

In Britain, executive agencies are responsible for the implementation of many executive functions of government and their personnel currently make up over fifty percent of the British 
civil service.[LINK TO ENDNOTE 3] The organizational form emerged beginning in 1988, in response to a review which recommended a more business-like, managerialist approach to the delivery of government services (Jenkins et al. 1988). The tasks of executive agencies range from internal government services and frontline service delivery to regulation and research. Examples include driver licensing, issuing passports, controlling borders, maritime safety, logistics support to the armed forces, delivery of social security benefits, and the procurement of government services. From 1988 these tasks, traditionally performed directly by government departments, were gradually moved into the executive agencies. The agencies are different from bodies such as ‘quangos' (quasi-autonomous non-governmental organizations), also known as 'non-departmental public bodies', which have more formal independence from ministers and report to other overseers, generally independent boards (Horton and Jones 1996; James 2003; Hood and Lodge 2006; Flinders 2009).

The appointment of executive agency chief executives is monitored by the Civil Service Commissioners. None of the chief executives are political appointees, in contrast to many of the appointments examined by Lewis (2007) in his study of U.S. federal agencies. The selection process follows standard procedures of merit based criteria and fair competition, with the search process headed by the agency's parent government department and the appointment process approved by the Civil Service Commissioners. Insiders or outsiders to central government, or the broader public sector, may be recruited through these processes.

Our dependent variable is the length of a chief executive's length of tenure, measured in financial years. Consistent with existing research on chief executive turnover (Boyne et al. 2010a; 2010b), our data do not attempt to distinguish so called forced from voluntary departures. Such distinctions are difficult to make because chief executives in most contexts, including 
British central government, are rarely 'fired' in a formal sense that allows a simple dichotomy between voluntary and forced exit to be unambiguously identified. Even in other public sector contexts where formal dismissals are more prevalent, a range of forms of departure have been identified as alternatives to firing including being 'pressured to resign to avoid being fired' and fleeing from an ‘intolerable situation’ (Whitaker and DeHoog 1991). More generally, tenure endings are often the result of a complex mix of push as well as pull factors and we focus on tenure ending in terms of the different destinations of the chief executive which we identified in our data for exit to elsewhere in central government, exit to the broader public sector, exit to the private sector and exit to formal retirement.

We gathered information about tenure length from the Whitehall Companion, a published source which documents annually the biographical and career histories of civil servants and ministers in British central government, as well as executive agency annual reports containing start and finish dates of chief executives' employment contracts. Information about the career destinations of chief executives was obtained from Who's Who (online version), from web-based sources including CVs posted online, or from CVs or completed surveys sent to us directly following our requests.

The variable tenure length is depicted in the form of a survivor function in Figure 1, showing the proportions of chief executives still serving ("surviving") after a given number of years.[LINK TO ENDNOTE 4] The longest tenure length of a chief executive in the estimation sample is fourteen years. The mean tenure is 4.07 years and the median four years.

[Figure 1 about here] 
The overall pattern of tenure length is disaggregated for different types of exit in Figure 2. Whilst some aspects of the distributions are similar, the modal group varies with type of exit, being around four years for exit into the public sector, around three years for exits into the private sector, and around five years for exit into retirement. These distributions do not necessarily imply different relationships between the explanatory variables and the different forms of exit but they do show that there are differences in the length of tenure we seek to analyze.

[Figure 2 about here] 
The three hypotheses relate to the explanatory variables of chief executives' insider to central government or outsider background (hypothesis 1), performance as specified by the political overseer of each agency (hypothesis $2 \mathrm{a}$ and $2 \mathrm{~b}$ ), and political changes in central government (hypothesis 3).

The insiderness of an executive agency chief executive is captured by a dummy variable referring to his or her previous managerial post. Data on this were obtained from the Whitehall Companion, Who's Who, chief executives' online CVs, and a survey aimed at those for whom information was not available in the public domain. The included category (coded as 1) consists of chief executives who come from a managerial position from within central government, with the others being considered non-central government outsiders (coded as 0 ). Without controlling for any other variables, the median length of tenure for both central government insiders and outsiders is four years.

In the British parliamentary system with its fused powers, ministers and their departments are the main political overseers of executive agencies both in formal constitutional terms and in informal practice (James 2003; Hood and Lodge 2006). Each agency chief executive enjoys considerable managerial freedom within the aims and responsibilities set out by ministers in the agency's Framework Document (one per agency). While ministers are ultimately accountable for the agency's functions, chief executives are personally accountable to ministers for operational performance including the achievement of key organizational targets set by ministers (Cabinet Office 2006). Each agency discusses targets annually with the supervising ministerial department. The targets, of which there are on average ten per agency (in our estimation sample), are formally signed off by ministers, with each agency required to report publicly on them each year. Whilst the targets change from time to time, the percentage of targets met 
provides a useful measure of performance against dimensions agreed as important with the key overseer each year.

Gaming is a concern about any system of performance management. In British central government in the period of our study, gaming consisted of creative compliance rather than falsification (Hood 2006). At least in some cases, targets were agreed upon in negotiation between chief executives and ministers. Some agency heads may have felt a target had been set too high by the minister, and anecdotal evidence suggests that in at least a few cases ministers and agency heads came to an agreement about the level at which a target should be set, the number of targets, or targets which should be dropped - either for being unrealistic or because they were no longer relevant.[LINK TO ENDNOTE 5]

We focus on how agencies fare in target achievement relative to other agencies. This provides a simple yardstick for ministers to see how an agency performs, compared to other agencies. Ambitious ministers are likely to be concerned about the performance of agencies for which they are responsible, including through wanting to impress the Prime Minister in order not to be fired and to be rewarded with promotion to a more senior ministerial post (Huber and Martinez-Gallardo 2008; Berlinski, Dewan and Dowding 2012). We generate dummy variables for high and low performance in target achievement relative to all agencies within the same financial year. High performance is defined here as a target achievement percentage more than one standard deviation above the within-financial year mean of all agencies, while low performance is defined as a target achievement percentage more than one standard deviation below the within-financial year mean of all agencies. These performance indicators refer to the previous financial year as performance data against annual targets do not fully become available until the end of a financial year. The data were gathered from the annual 'Next Steps Reviews' 
that covered the set of agencies for part of the period (up to 1999), and individual agency annual reports, as laid before the House of Commons, for the rest of the period.

To operationalize political change, we include separate dummy variables for a change in party control and a succession in the minister overseeing an agency, in each case both in the current financial year as well as in the previous financial year. Changes in party control occurred in financial years 1997/98 (from the Conservatives to Labour) and 2010/11 (from Labour to the coalition of the Conservatives and Liberal Democrats).

We include a set of control variables. The first set captures confounding chief executive characteristics and the second set characteristics of executive agencies. Chief executive characteristics include dummies for whether a chief executive has at least a Bachelor's degree, which might increase job opportunities, and whether he or she was educated at either Oxford or Cambridge. We suggest this latter influence raises net risk of exit through a combination of these institutions' relatively large informal alumni networks and human capital associated with the highly selective entry to those universities which both increase opportunities for career advancement and to a lesser extent, give some protection against involuntary exit. Further we control for age, which is positively related with retirement, and for female chief executives because of the relative lack of women in senior positions and concerns about equal opportunities for this group which might increase risk of exit. Data for variables age and education were obtained from the same sources as for previous managerial experience discussed above. Without controlling for any other variables, the median length of tenure for both women is three years, whereas it is four years for men.

We control for a number of agency characteristics that might affect agency head tenure. The first is the number of full-time equivalent (FTE) employees, as a proxy for both the size and 
the operational resources allocated to an agency, which could offer some protection against exit and also suggests more resources available which, on balance, would likely allow higher rewards for the chief executive, encouraging them to stay. Information on the number of FTE employees was obtained from 'Civil Service Statistics' available on the British Government's civil service website as well as agencies' annual reports. Second, we include a dummy for whether the agency has a regulatory function. This could plausibly allow the chief executive to be more resistant to pressures from ministers, including to leave. Regulatory agencies often operate programs based on strong legislation, making it more difficult for politicians to encourage the agency head to move on without risking looking like political interference undermining the credibility of regulatory systems. The base category consists of agencies carrying out other functions.[LINK TO ENDNOTE 6] This categorization of agencies is more fitting to the British context than one that groups agencies by "partisanship," where one party is much more favorable to an agency than another (Gilmour and Lewis 2006). Such differences are small in the United Kingdom compared to the United States. Third, we include a dummy for whether an agency has trading fund status in a given year (with data on this obtained from Agencies' Framework Documents). Trading fund status means that an agency is allowed to raise its own funding through user fees (e.g. fees collected by the Driver Vehicle Licensing Agency) or the sale of merchandise (e.g. the sale of maps by the Ordnance Survey). Such agencies do not fully depend on appropriations, which could in turn affect the length of chief executive tenure including by making the post more autonomous from ministerial pressure and more attractive to remain in. We control for media attention paid to the agency, defined as the number of newspaper stories about each agency each year, as a proxy for the broader interest by members of the public and others in the agency. Media coverage captures aspects of broader performance of the agency 
beyond those included in performance targets set by ministers. The substantial negativity bias in press reporting of public service performance suggests that this coverage is often a sign of poor performance but the variable also captures more general interest in the agency's activities, including reforms in the policy sector the agency is involved in. We counted the number of stories included in the Nexis British newspapers data base referring to the agency within a financial year. In the next step, we obtained the over-time mean and standard deviation of the number of media stories for each agency over its life-span within our data set. Finally, for each observation (agency-financial year), we calculate a z-score of the number of media stories. The z-scores indicates the number of media stories away from the mean measured in units of the standard deviation of media stores for the agency. The resulting measure shows whether media attention in the year is atypical. Summary statistics for all variables are provided in Table

\section{1.[LINK TO ENDNOTE 7]}

[Table 1 about here]

To complement the summary statistics, in Table 2 we provide a transition matrix for all chief executives whose tenure at an agency ends within our data set. The table shows their insider/outsider status to central government stemming from their previous appointment and the form of their tenure ending (continuing in the public sector, exiting to the private sector, or exiting into formal retirement). For chief executives recruited from within the central state, the modal exit is formal retirement. In our estimation sample, the tenure of 51 percent of the chief executives who are central government insiders ended in this way. For chief executives coming 
from beyond central government, retirement accounts for just 17 percent of exits, with a far higher proportion of exits to the private sector.

[Table 2 about here]

In our models, the chief executives' length of tenure in years is our dependent variable, defined as the time from appointment to exiting the role. We set out by analyzing the data using a Cox (1972) proportional hazards survival model[LINK TO ENDNOTE 8] where all types of tenure ending are pooled. Next, we use a competing risks model (Fine and Gray 1999) [LINK TO ENDNOTE 9] to test the hypotheses in the context of different types of exit from a chief executive appointment: (i) taking a post in central government or elsewhere in the public sector (e.g. local government); (ii) leaving for the private or nonprofit sector; and (iii) formally retiring. The models cover 247 chief executive tenure spells. 142 of these 247 spells end within the estimation sample. The remaining spells continue beyond the end of the data, i.e. these chief executives were still serving at the end of our data. Both of our models account for this. Each agency chief executive becomes at risk of leaving upon assuming a post.

Our models leave the baseline hazard unspecified, removing the need to make assumptions about it. We present hazard ratios from exponentiated coefficients of variables in the models to show the relationship between our explanatory variables and length of tenure. [LINK TO ENDNOTE 10] 


\section{Findings}

We first consider the findings from the pooled analysis, where all types of exit from a chief executive position are analyzed together. These results are shown in Table 3.

[Table 3 about here]

In the pooled analysis, there is no evidence that civil service insiders have a different length of tenure than those recruited from elsewhere. There is also no statistical association between target achievement and length of tenure.[LINK TO ENDNOTE 11] A change in party control last year was associated with a 44 percent lower hazard of exit but this association is noisy. When all other explanatory variables are held at their means, the probability of an agency head's exit after four years of service decreases from 0.14 to 0.08 .

The pooled analysis shows the overall pattern for the single outcome of an end to tenure, regardless of where chief executives go next. Our second set of models disaggregate the outcomes into different types to assess the variables' association with the risk of tenure ending in a particular type of exit. Null findings for hypothesized variables in the pooled model may mask a pattern where a variable is associated with a longer or shorter length of tenure for one type of exit but not in aggregate. Variables meeting conventional levels of statistical significance that are associated with shorter or longer tenure in aggregate may not be similarly associated across all the types of exit. The competing-risks analysis reported in Table 4 provides insight into patterns for each type of tenure ending. 
[Table 4 about here]

In contrast to the null finding on civil service insiders in the pooled model, this personal characteristic had a nuanced relationship with risk of exit depending on the destination. Civil service insiders were much more likely than agency heads with other backgrounds to leave for another post in the public sector (195 percent higher hazard). Holding all other explanatory variables at their means, the probability of an agency head's exit after four years of service to another post in the public sector is 0.12 if they are a civil service insider but only 0.04 if they are not. There is a similar pattern for exits into retirement (370 percent higher hazard). Holding all other explanatory variables at their means, the probability of an agency head's retirement after four years of service is 0.04 if they are a civil service insider but only 0.01 if they are not. By contrast, civil service insiders were much less likely to exit into the private sector (72 percent lower hazard). Holding all other explanatory variables at their means, the probability of an agency head's exit after four years of service to the private sector is 0.02 if they are a civil service insider but 0.04 if they are not.

Next, looking at the performance-tenure association again by type of exit, we find that chief executives who eventually exited into the public sector had a lower risk of departing if their agency's performance was high relative to other agencies last year. In such cases, chief executives' hazard of departure was 71 percent lower. Conversely, for chief executives who went on to formally retire after their current work as agency chief executive, we find that a relatively low target achievement rate was associated with a 122 percent higher hazard of retiring. 
Finally, we see that the lower risk associated with a change in party control (which we found in the pooled model reported in Table 3) was driven by chief executives who exited into formal retirement. The risk of these chief executives to exit into formal retirement was 66 percent lower.

\section{Discussion}

The findings reveal that Hypothesis 1, that insiders to central government will have a lower risk of exit (i.e. a longer tenure) than non-insiders across all exit types, is not supported. Civil service insiders appear to be rather mobile within the public sector since they show an increased risk of exiting into another public organization. They are also more likely to retire. Note that civil service insiders who retire in our estimation sample have a mean age of 58 years, whereas the mean age of all other retirements is 61 years. The difference is statistically significant.

In line with the expectation expressed in hypothesis $2 \mathrm{a}$, that agency heads will retire sooner if they oversee low performance, the competing risks analysis shows a positive association between low agency performance (relative to mid-range performance) and shortened tenure of those chief executives going on to formal retirement. Chief executives can be encouraged by superiors in agencies' parent departments to leave by this route for reasons of low performance and there is somewhere for them to go that is not dependent on other job offers

(they retire). Among the agency heads who retire in our estimation sample, those who retire following low performance have a mean age of 57 , whereas the other retirements have a mean 
age of 59. The difference is statistically significant. Executive agencies in Britain and other parliamentary systems are supposed to be performance based organizations. Our finding for poor performance is consistent with the implementation of this model of running government services in practice.

Hypothesis $2 b$ that agency heads overseeing high performance will have a higher risk of exit (i.e. a shorter tenure) than other agency heads, is not supported, except for the null finding on agency heads headed for formal retirement. Rather, agency heads overseeing high performance are less likely to exit into another public sector organization. Perhaps this is encouraging because the well performing agencies are able to hold on to them.

Hypothesis 3, that agency heads serving during a political change will have a higher risk of exit is not supported. Agency heads who go on to formal retirement tend to stay longer following a change in party control suggesting that officials can hang on to tenure following political change if they choose to do so.

Having found systematic differences in the likelihoods that agency heads exit their post, depending both on their background and their destination, we have begun bringing the study of realized turnover among senior managers in the public sector closer to the rich private sector literature.

\section{Limitations}

As we have already mentioned in introducing the decision calculus of agency heads, our research may be affected by selection of different kinds of people into agency head positions. Such a 
problem is difficult to overcome in research designs that are unable randomly to allocate different types of people into agency positions, and such a design is not practical for this topic area. Consistent with much non-experimental research, caution is needed in the extent to which the results can be considered causal. However, we include an extensive set of controls for agency heads' characteristics to try to restrict the degree to which this limitation is a problem in this case. Further, assumptions are required to make generalizations beyond the case of the United Kingdom during the time period we study, but we suggest that they are of broad relevance to parliamentary systems using performance oriented organizations to handle central government executive activities. Finally, while we have a substantial number of observations sufficient to generate statistical power for our analysis, the number of exits we observe (cf. Table 2) does not enable us to further break down agency head background and destination into finer categories beyond the main ones we examine.

\section{Conclusions}

Recent decades have seen a focus on bringing in outsiders as managers from beyond central government both in Britain and many other systems (Hood, 1991; Cabinet Office, 1999; James, 2001, 2003; Pollitt and Bouckaert, 2004; Hood and Lodge, 2006; HM Government, 2007; Richards, 2007). The flip side of our finding that insiders stay relatively longer before exiting to the private sector is that non-insiders stay a shorter time, suggesting that retention of this group is relatively more difficult. Policymakers need to be mindful of this issue because retaining highly qualified personnel, and replacing those who leave with people who will stay, is an ongoing 
challenge for public organizations (Lewis 1991). The issue is pressing given the aging public sector workforce which reduces the size of the insider pool. In Britain, 44 percent of civil servants were aged 40 years or older in 1991 whilst by 2011 this proportion had risen to 68 percent (Office for National Statistics 2012). Similar issues are apparent in many other public sectors, including the U.S. federal government (Partnership for Public Service 2010, 4-5), making it vital to understand the factors that shorten officials' tenure.

We find no evidence of change in political control increasing risk of retirement, suggesting that political interference by this route is not substantial for this category of public manager. Much of the literature on tenure has been written in the context of much less merit protection for officials' tenure (Whitaker, Gordon, and Ruth DeHoog. 1991; Feiock, and Stream 1998). Our findings also contrast with evidence suggesting political influence on tenure in some other formally merit based tenure protected systems, notably senior officials in local government in England (Boyne et al 2010a). It appears that systems to protect merit-based tenure are working for agency heads in central government tasked with managing executive functions. At the same time, even within central government, the pattern would likely be different for policy officials in the parent departments overseeing the agencies because this group of officials work more closely with ministers on policy development -and are more closely analogous to the senior officials in local government who combine policy and executive roles. Future research should examine the different influences on length of tenure of different types of official within central government because it is likely that our findings are most relevant for 'performance based' executive organizations. Additionally, in settings where it is possible to obtain proxies for administrators' political preferences, research should explore this outcome further by examining political ideal points of public officials and politicians in local and central government contexts 
of parliamentary systems with and without merit protections, following Clinton et al.'s (2012) approach in the U.S. Such research would shed further light on the role of political preferences as a mechanism in bringing about exit from administration following political change.

\section{Authors' Note}

Upon publication, data and code to reproduce the results reported in this article will be made available at the Harvard Dataverse repository. A direct link will be provided at the corresponding author's webpage: http://www.petrovsky.ws

\section{Acknowledgments}

We thank the editors, three anonymous reviewers, and seminar participants at Ohio State University for valuable comments. Support for this research was provided by the UK Economic and Social Research Council (Chief Executive Succession and the Performance of Central Government Agencies, grant no RES-062-23-2471).

\section{Notes}

1. An additional, interesting avenue might be to use political campaign contributions to estimate public managers' preferences (Bonica et al. 2015), but that requires such information to be public, which is not the case in many parliamentary systems, including in Britain. 
2. We analyze executive agencies formally in the purview of central government ministers in Great Britain. Northern Ireland had different arrangements including a separate civil service and periods both of devolved power and UK government control, making the political control and insider/outsider arrangements different from Britain.

3. As of March 31, 2012; data from our own dataset used in this article.

4. All figures and descriptive statistics are for the common estimation sample of our models.

5. We conducted two empirical checks to examine whether there are patterns consistent with gaming. First, we reviewed target churn, that is, the percentage of targets in a year that are new because that could reflect the substitution of new, perhaps although not necessarily, easier targets. We examined whether the rate of target churn depends on the number of years of an agency head's tenure. Regressing the percentage of targets that are new in a year on the number of years the agency head has service, we find a weak negative relationship, with an additional year in their job predicting a one-percentage point lower rate of target churn. This pattern is not consistent with gaming. Second, we examined whether the number of years an agency head has served predicts the rate of target achievement, which would be consistent with agency heads learning how to game over time to improve target performance. We do not find evidence of such a relationship. Overall, we find very little evidence in accordance with gaming. 
6. As a robustness check, we re-estimated our models with the addition of dummies for all parent departments. First, in the pooled model, only three out of thirty-six department dummies had a statistically significant hazard ratio: Department for Innovation, Universities \& Skills;

Department for Constitutional Affairs; and Treasury Solicitor's Department. We note that this is not much more of a pattern than would be expected by chance so it does not appear that there are important differences between ministries of this kind. Second, in that model, our findings are largely unchanged (the two exceptions are that the hazard ratios on party political change and number of agency employees now become statistically insignificant using a .1 cutoff). In the competing risks model, for exits into the public and private sectors, the relative risk ratios are unchanged in statistical significance and close numerically. For exits into retirement, the only differences are that the relative risk ratios on party political change, trading fund status, and number targets now become statistically insignificant using a .1 cutoff. We argue that agency function, not parent department, is the appropriate control for differences in expectations about performance, and different working environments for agency heads more generally.

7. The table also shows summary statistics for the raw number of media stories, to help the reader put the z-scores we use in the analysis into context.

8. The main assumption behind Cox's (1972) survival modeling approach is that hazards are proportional; in other words, if an explanatory variable doubles the hazard of agency heads' exit in one year, it also doubles the hazard in any other year. We test this assumption and find it supported. The main advantage of the Cox model is that no assumptions are required about the baseline hazard; it is not estimated. 
9. Similarly to the Cox model, the Fine and Gray (1999) competing risks estimator requires hazards to be proportional. Also similarly, the baseline hazard is not estimated and therefore, no assumptions about it are required.

10. We tested the appropriateness of the proportional hazards assumption required by our models. To do so, we included interactions of time with all time-varying covariates. The null hypothesis was not rejected for any of these interactions.

11. As a robustness check, we estimated both the pooled and the competing risks models with a linear target achievement percentage variable instead of the dummies for high and low target achievement. In the pooled model (variation of Table 3), the linear target achievement rate is not statistically associated with length of tenure. In the competing risks model (variation of Table 4), it is positively associated with length of tenure for chief executives who exited to another central government position: A one percentage point increase in the target achievement rate is associated with a two percent lower risk of exit into another position in the public sector. 


\section{References}

Behn, Robert D. 2003. Why Measure Performance? Different Purposes Require Different Measures. Public Administration Review 63(5): 586-606.

Berlinski, Samuel, Torun Dewan, and Keith Dowding. 2012. Accounting for Ministers: Scandal and Survival in British Government 1945-2007. Cambridge: Cambridge University Press.

Bonica, Adam, Jowei Chen, and Tim Johnson. 2015. Senate Gate-Keeping, Presidential Staffing of 'Inferior Offices,' and the Ideological Composition of Appointments to the Public Bureaucracies. Quarterly Journal of Political Science 10: 5-40.

Boyne, George A., and Jay Dahya. 2002. Executive Succession and the Performance of Public Organizations. Public Administration 80(1): 179-200.

Boyne, George A., Oliver James, Peter John, and Nicolai Petrovsky. 2010a. Does Political Change Affect Senior Management Turnover? An Empirical Analysis of Top-Tier Local Authorities in England. Public Administration 88(1): 136-53.

Boyne, George A., Oliver James, Peter John, and Nicolai Petrovsky. 2010b. Does Public Service Performance Affect Top Management Turnover?. Journal of Public Administration Research and Theory 20(2): 261-79. 
Bozeman, Barry. 1987. All Organizations are Public. London: Jossey-Bass.

Cabinet Office. 1999. Modernising Government. London: HMSO.

Cabinet Office. 2006. Executive Agencies: A Guide for Departments.

https://www.gov.uk/government/uploads/system/uploads/attachment_data/file/80076/exec_agenc ies_guidance_oct06_0.pdf [accessed May 31, 2016].

Clinton, Joshua D., Anthony Bertelli, Christian R. Grose, David E. Lewis and David C. Nixon. 2012. Separated Powers in the United States: The Ideology of Agencies, Presidents, and Congress. American Journal of Political Science 56(2): 341-54.

Cox, David R. 1972. Regression Models and Life-Tables. Journal of the Royal Statistical Society, Series B (Methodological) 34(2): 187-220.

Dowding, Keith M., and Peter John. 2012. Exits, Voices and Social Investments; Citizens Reaction to Public Services. Cambridge: Cambridge University Press.

Ennser-Jedenastik, Laurenz. 2014. Political Control and Managerial Survival in State-Owned Enterprises. Governance 27(1): 135-61.

Feiock, Richard C. and Christopher Stream. 1998. Explaining the Tenure of Local Government Managers. Journal of Public Administration Research and Theory 8(1): 117-30. 
Fine, Jason P. and Robert J. Gray. 1999. A Proportional Hazards Model for the Subdistribution of a Competing Risk. Journal of the American Statistical Association 94(446): 496-509.

Finkelstein, S., D.C. Hambrick and A.A. Cannella. 2009. Strategic Leadership: Theory and Research on Executives, Top Management Teams and Boards. Oxford: Oxford University Press.

Flinders, Matthew. 2009. The Politics and Politicization of Delegation. In The Oxford Handbook of British Politics, edited by Matthew Flinders, Andrew Gamble, Colin Hay, and Michael Kenny, 303-324. Oxford: Oxford University Press.

Fredrickson, James W., Donald C. Hambrick, and Sara Baumrin. 1988. A Model of CEO Dismissal. Academy of Management Review 13(2): 255-70.

Furtado, Eugene P. H., and Vijay Karan. 1990. Causes, Consequences, and Shareholder Wealth Effects of Management Turnover: A Review of the Empirical Evidence. Financial Management 19(2): 60-75.

Gilmour, John B. and David E. Lewis. 2006. Does Performance Budgeting Work? An Examination of the Office of Management and Budget's PART Scores. Public Administration Review 66 (5): 742-52. 
Grissom, Jason A., and Stephanie Andersen. 2012. Why Superintendents Turn Over. American Educational Research Journal 49(6): 1146-80.

Grissom, Jason A., Samantha L. Viano, and Jennifer L. Selin. 2016. Understanding Employee Turnover in the Public Sector: Insights from Research on Teacher Mobility. Public Administration Review 76(2): 241-251.

Hambrick, Donald C., and Phyllis A. Mason. 1984. Upper Echelons: The Organization as a Reflection of Its Top Managers. Academy of Management Review 9(2): 193-206.

Heinrich, Carolyn J. 2003. Measuring Public Sector Performance and Effectiveness. In The SAGE Handbook of Public Administration, $2^{\text {nd }}$ ed., edited by B. Guy Peters and Jon Pierre, 3249. London: SAGE.

Hess, Frederick M. 1998. Spinning Wheels: The Politics of Urban School Reform. Washington, D.C.: Brookings Institution Press.

HM Government. 2007. Skills for government: government response to the committee's ninth report of session 2006-07, second report of session 2007-08.

https://www.publications.parliament.uk/pa/cm200708/cmselect/cmpubadm/89/89.pdf [accessed May 31, 2016]. 
Hill, Carolyn J., and Laurence E. Lynn. Jr. 2009. Public Management: A Three-Dimensional Approach. Washington D.C.: CQ Press.

Hirschman, Albert O. 1970. Exit, Voice, and Loyalty: Responses to Decline in Firms, Organizations, and States. Cambridge, MA: Harvard University Press.

Hood, Christopher. 1991. A Public Management for All Seasons?. Public Administration 69(1): $3-19$.

Hood, Christopher. 2006. Gaming in Targetworld: The Targets Approach to Managing British Public Services. Public Administration Review 66(4): 515-21.

Hood, Christopher, and Martin Lodge. 2006. The Politics of Public Service Bargains: Reward, Competency, Loyalty - and Blame. Oxford: Oxford University Press.

Horton, Sylvia, and Jacqui Jones. 1996. Who are the New Public Managers? An Initial Analysis of "Next Steps" Chief Executives and Their Managerial Roles. Public Policy and Administration 11(4): 18-44.

Huber, John D., and Cecilia Martinez-Gallardo. 2008. Replacing Cabinet Ministers: Patterns of Ministerial Stability in Parliamentary Democracies. American Political Science Review 102(2): $169-80$. 
James, Oliver. 2001. Business Models and the Transfer of Business-Like Central Government Agencies. Governance 14(2): 233-52.

James, O. 2003. The Executive Agency Revolution in Whitehall: Public Interest versus BureauShaping Explanations. Basingstoke, UK: Palgrave Macmillan.

James, Oliver, and Sandra van Thiel. 2010. Structural Devolution to Agencies. In The Ashgate Companion to New Public Management, edited by Tom Christensen, and Per Lægreid, 209-22. Farnham, Surrey: Ashgate Publishing, Ltd.

Jenkins, Kate, Karen Caines, and Andrew Jackson. 1988. Improving Management in Government: The Next Steps. Efficiency Unit, London: HMSO.

Karaevli, Ayse. 2007. Performance Consequences of New CEO outsiderness: Moderating Effects of Pre- and Post-Succession Contexts. Strategic Management Journal 28(7): 681-706.

Kopecký, Petr, Peter Mair, and Maria Spirova. 2012. Party Patronage and Party Government in European Democracies. Oxford: Oxford University Press.

Lewis, David. 2007. Testing Pendleton's Promise: Do Political Appointees make Worse Bureaucrats?. Journal of Politics 69(4): 1073-88. 
Bertelli, Anthony M., and David E. Lewis. 2013. Policy Influence, Agency-Specific Expertise, and Exit in the Federal Service. Journal of Public Administration Research and Theory 23(2): $223-45$.

Lewis, Gregory B. 1991. Turnover and the quiet crisis in the federal civil service. Public Administration Review 51(2): 145-55.

McCabe, Barbara C., Richard C. Feiock, James C. Clingermayer, and Christopher Stream. 2008. Turnover Among City Managers: The Role of Political and Economic Change. Public Administration Review 66(2): 380-86.

Miller, Danny. 1991. Stale in the Saddle: CEO Tenure and the Match between Organization and Environment. Management Science 73(1): 34-52.

Mintzberg, Henry. 1975. The Manager's job: Folklore and Fact. Harvard Business Review 53(4): 49-61.

Moynihan, Donald P. 2008. The Dynamics of Performance Management: Constructing Information and Reform. Washington, D.C.: Georgetown University Press.

Norburn, David. 1989. The Chief Executive: A Breed Apart. Strategic Management Journal 10(1): 1-15. 
Office for National Statistics. 2012. Civil Service Statistics: 2012.

http://www.ons.gov.uk/employmentandlabourmarket/peopleinwork/publicsectorpersonnel/bulleti ns/civilservicestatistics/2012-10-24 [accessed May 31, 2016].

Partnership for Public Service. 2010. Beneath the Surface: Understanding Attrition at Your Agency and Why It Matters.

https://www.boozallen.com/content/dam/boozallen/media/file/Understanding_Attrition-atYour_Agency.pdf [accessed May 31, 2016].

Petrovsky, Nicolai, Oliver James, and George A. Boyne. 2015. New Leaders' Managerial Background and the Performance of Public Organizations: The Theory of Publicness Fit. Journal of Public Administration Research and Theory 25(1): 217-36.

Pollitt, Christopher, and Geert Bouckaert. 2004. Public Management Reform: A Comparative A Analysis, 2nd edition. NY: Oxford University Press.

Pollitt, Christopher, and Colin Talbo. 2004. Unbundled Government: A Critical Analysis of the Global Trend to Agencies, Quangos and Contractualisation. London and NY: Routledge.

Radin, Beryl A. 2006. Challenging the Performance Movement: Accountability, Complexity, and Democratic Values. Washington, D.C.: Georgetown University Press. 
Richards, David. 2007. New Labour and the Civil Service: Reconstituting the Westminster Model. Basingstoke: Palgrave.

Teodoro, Manuel P. 2011. Bureaucratic Ambition: Careers, Motives, and the Innovative Administrator. Baltimore, MD: Johns Hopkins University Press.

Van Wart, Montgomery. 2003. Public-Sector Leadership Theory: An Assessment. Public Administration Review 63(2): 214-28.

Verhoest, KKoen, Sandra Van Thiel, Geert Bouckaert, and Per Laegreid. 2011. Government Agencies: Practices and Lessons from 30 Countries. Basingstoke, Hampshire: Palgrave Macmillan.

Whitaker, Gordon, and Ruth DeHoog. 1991. City Managers Under Fire: How Conflict Leads to Turnover. Public Administration Review 51(2): 156-65.

Wood, B. Dan, and Richard W. Waterman. 1994. Bureaucratic Dynamics: The Role of Bureaucracy in a Democracy. Boulder, CO: Westview Press.

Wood, B. Dan, and Miner P. Marchbanks. 2008. What Determines How Long Political Appointees Serve?. Journal of Public Administration Research and Theory 18(3): 375-96. 
Zana, Edward J. 1990. CEO Selection, Succession, Compensation and Firm Performance: A Theoretical Integration and Empirical Analysis. Strategic Management Journal 11(3): 217-30.

Zhang, Yan, and Nandini Rajagopalan. 2004. When the Known Devil is Better than the Unknown God: An Empirical Study of the Antecedents and Consequences of Relay CEO Successions. Academy of Management Journal 47(4): 483-500. 


\section{Tables and Figures}

Table 1: Summary statistics for the estimation sample

(934 years covering 247 chief executive spells, 142 of which end within the sample)

\begin{tabular}{|c|c|c|c|c|}
\hline & Mean & $\begin{array}{l}\text { Standard } \\
\text { deviation }\end{array}$ & Minimum & Maximum \\
\hline \multicolumn{5}{|l|}{ Dependent variable: } \\
\hline Agency head length of tenure (years) & 4.07 & 2.45 & 1 & 14 \\
\hline \multicolumn{5}{|l|}{ Hypothesis 1: insider status } \\
\hline $\begin{array}{l}\text { Agency head came from central government } \\
\text { (dummy) }\end{array}$ & 0.70 & 0.46 & 0 & 1 \\
\hline \multicolumn{5}{|l|}{ Hypothesis 2: performance } \\
\hline $\begin{array}{l}\text { High performance relative to all agencies } \\
\text { (dummy) }\end{array}$ & 0.19 & 0.39 & 0 & 1 \\
\hline $\begin{array}{l}\text { Low performance relative to all agencies } \\
\text { (dummy) }\end{array}$ & 0.18 & 0.38 & 0 & 1 \\
\hline \multicolumn{5}{|l|}{ Hypothesis 3: political change } \\
\hline Change in party control last year (dummy) & 0.11 & 0.31 & 0 & 1 \\
\hline Change in party control this year (dummy) & 0.11 & 0.31 & 0 & 1 \\
\hline $\begin{array}{l}\text { Change in overseeing minister last year } \\
\text { (dummy) }\end{array}$ & 0.50 & 0.50 & 0 & 1 \\
\hline $\begin{array}{l}\text { Change in overseeing minister this year } \\
\text { (dummy) }\end{array}$ & 0.42 & 0.49 & 0 & 1 \\
\hline \multicolumn{5}{|l|}{ Controls for agency head characteristics: } \\
\hline Bachelor's degree or higher (dummy) & 0.77 & 0.42 & 0 & 1 \\
\hline Oxford or Cambridge education (dummy) & 0.21 & 0.41 & 0 & 1 \\
\hline Agency head's age in years & 53.16 & 5.17 & 34.61 & 66.30 \\
\hline Female agency head (dummy) & 0.12 & 0.32 & 0 & 1 \\
\hline \multicolumn{5}{|l|}{ Controls for agency characteristics: } \\
\hline Agency employees (FTE) & 2453.98 & 7278.71 & 30 & 72003 \\
\hline Regulatory agency (dummy) & 0.21 & 0.41 & 0 & 1 \\
\hline Trading fund status (dummy) & 0.25 & 0.43 & 0 & 1 \\
\hline $\begin{array}{l}\% \text { of all targets last year that cover outcomes } \\
\text { or efficiency }\end{array}$ & 13.58 & 13.98 & 0 & 100 \\
\hline Number of targets last year & 9.68 & 6.78 & 1 & 84 \\
\hline Media stories last year Z-score & -0.06 & 0.91 & -2.13 & 4.32 \\
\hline Raw number of media stories last year & 81.49 & 149.47 & 0 & 994 \\
\hline Media stories this year Z-score & 0.04 & 0.91 & -1.97 & 4.32 \\
\hline Raw number of media stories this year & 86.60 & 158.20 & 0 & 994 \\
\hline
\end{tabular}


Table 2: Transition matrix of agency heads (insider to central government or outsider appointment form of tenure ending; there are 142 endings within the estimation sample)

\begin{tabular}{llll}
\hline \hline & $\begin{array}{l}\text { Agency head exits } \\
\text { to: }\end{array}$ & & \\
& Public sector & Private sector & Formal retirement \\
\hline $\begin{array}{l}\text { Insider from central } \\
\text { government }\end{array}$ & 33 & 19 & 54 \\
$\begin{array}{l}\text { Outsider from } \\
\text { beyond central }\end{array}$ & $(31.1 \%)$ & $(17.9 \%)$ & $(50.9 \%)$ \\
government & 6 & 24 & 6 \\
\hline \hline
\end{tabular}

Rounded row percentages are listed in parentheses 
Table 3: Pooled Cox analysis of agency head length of tenure

\begin{tabular}{lc} 
Explanatory variables: & Any exit \\
\hline & \\
Agency head came from central & 1.27 \\
government (dummy) & $(1.12)$ \\
High performance relative to all & 1.17 \\
agencies (dummy) & $(0.68)$ \\
Low performance relative to all & 1.38 \\
agencies (dummy) & $(1.47)$ \\
Change in party control last year & $0.56^{*}$ \\
(dummy) & $(-1.68)$ \\
Change in party control this year & 0.85 \\
(dummy) & $(-0.52)$ \\
Change in overseeing minister & 1.10 \\
last year (dummy) & $(0.52)$ \\
Change in overseeing minister & 0.93 \\
this year (dummy) & $(-0.38)$ \\
Bachelor's degree or higher & 0.90 \\
(dummy) & $(-0.50)$ \\
Oxford or Cambridge education & $1.84 * * *$ \\
(dummy) & $(2.83)$ \\
Agency head's age in years & $1.07 * * *$ \\
& $(3.35)$ \\
Female agency head (dummy) & 0.73 \\
& $(-0.95)$ \\
Agency employees (FTE) & $1.00^{* *}$ \\
& $(2.15)$ \\
Regulatory agency (dummy) & 0.83 \\
& $(-0.79)$ \\
Trading fund status (dummy) & 0.88 \\
& $(-0.57)$ \\
\% of all targets last year that cover & 0.99 \\
outcomes or efficiency & $(-1.64)$ \\
Number of targets last year & 0.99 \\
& $(-0.79)$ \\
Media stories last year Z-score & 0.87 \\
& $(-1.35)$ \\
Media stories this year Z-score & 1.05 \\
& $(0.50)$ \\
Agency head spells & -613.32 \\
\hline Agency head tenure endings & 247 \\
\hline Observations & 142 \\
\hline Log likelihood & 934 \\
\hline
\end{tabular}

We report hazard ratios (exponentiated coefficient estimates). A hazard ratio greater than one indicates that an explanatory variable is associated with a shorter time until an exit from the agency head position. We report zstatistics in parentheses below the hazard ratios $\left(* * * \mathrm{p}<0.01, * * \mathrm{p}<0.05,{ }^{*} \mathrm{p}<0.1\right)$. 
Table 4: Competing risks analysis of agency head length of tenure

\begin{tabular}{|c|c|c|c|}
\hline Explanatory variables: & $\begin{array}{c}(1) \\
\text { Public } \\
\end{array}$ & $\begin{array}{c}(2) \\
\text { Private } \\
\end{array}$ & $\begin{array}{c}\text { (3) } \\
\text { Retire }\end{array}$ \\
\hline $\begin{array}{l}\text { Agency head came from central } \\
\text { government (dummy) }\end{array}$ & $\begin{array}{l}2.95 * * \\
(2.55)\end{array}$ & $\begin{array}{l}0.28 * * * \\
(-4.04)\end{array}$ & $\begin{array}{c}4.70 * * * \\
(3.50)\end{array}$ \\
\hline $\begin{array}{l}\text { High performance relative to all } \\
\text { agencies (dummy) }\end{array}$ & $\begin{array}{l}0.29 * \\
(-1.72)\end{array}$ & $\begin{array}{c}1.75 \\
(1.40)\end{array}$ & $\begin{array}{c}1.68 \\
(1.48)\end{array}$ \\
\hline $\begin{array}{l}\text { Low performance relative to all } \\
\text { agencies (dummy) }\end{array}$ & $\begin{array}{c}1.46 \\
(1.11)\end{array}$ & $\begin{array}{c}0.67 \\
(-0.72)\end{array}$ & $\begin{array}{l}2.22 * * \\
(2.46)\end{array}$ \\
\hline $\begin{array}{l}\text { Change in party control last year } \\
\text { (dummy) }\end{array}$ & $\begin{array}{c}0.96 \\
(-0.07)\end{array}$ & $\begin{array}{c}0.68 \\
(-0.63)\end{array}$ & $\begin{array}{c}0.34 * \\
(-1.89)\end{array}$ \\
\hline $\begin{array}{l}\text { Change in party control this year } \\
\text { (dummy) }\end{array}$ & $\begin{array}{c}0.60 \\
(-0.74)\end{array}$ & $\begin{array}{c}1.78 \\
(1.33)\end{array}$ & $\begin{array}{c}0.49 \\
(-1.20)\end{array}$ \\
\hline $\begin{array}{l}\text { Change in overseeing minister } \\
\text { last year (dummy) }\end{array}$ & $\begin{array}{c}0.73 \\
(-1.00)\end{array}$ & $\begin{array}{c}1.45 \\
(1.14)\end{array}$ & $\begin{array}{c}1.14 \\
(0.53)\end{array}$ \\
\hline $\begin{array}{l}\text { Change in overseeing minister } \\
\text { this year (dummy) }\end{array}$ & $\begin{array}{c}0.89 \\
(-0.34)\end{array}$ & $\begin{array}{l}1.17 \\
(0.46)\end{array}$ & $\begin{array}{c}0.99 \\
(-0.03)\end{array}$ \\
\hline $\begin{array}{l}\text { Bachelor's degree or higher } \\
\text { (dummy) }\end{array}$ & $\begin{array}{c}0.55 \\
(-1.31)\end{array}$ & $\begin{array}{l}1.35 \\
(0.62)\end{array}$ & $\begin{array}{c}0.86 \\
(-0.54)\end{array}$ \\
\hline $\begin{array}{l}\text { Oxford or Cambridge education } \\
\text { (dummy) }\end{array}$ & $\begin{array}{l}2.51 * * \\
(2.50)\end{array}$ & $\begin{array}{c}1.19 \\
(0.46)\end{array}$ & $\begin{array}{c}1.00 \\
(0.01)\end{array}$ \\
\hline Agency head's age in years & $\begin{array}{l}0.90 * * * \\
(-3.36)\end{array}$ & $\begin{array}{l}1.06^{*} \\
(1.71)\end{array}$ & $\begin{array}{c}1.39 * * * \\
(8.44)\end{array}$ \\
\hline Female agency head (dummy) & $\begin{array}{c}0.72 \\
(-0.70)\end{array}$ & $\begin{array}{c}0.40 \\
(-1.52)\end{array}$ & $\begin{array}{c}1.71 \\
(1.00)\end{array}$ \\
\hline Agency employees (FTE) & $\begin{array}{c}1.00 \\
(1.16)\end{array}$ & $\begin{array}{c}1.00 \\
(0.45)\end{array}$ & $\begin{array}{c}1.00 \\
(0.67)\end{array}$ \\
\hline Regulatory agency (dummy) & $\begin{array}{c}1.43 \\
(0.93)\end{array}$ & $\begin{array}{l}1.23 \\
(0.56)\end{array}$ & $\begin{array}{c}0.91 \\
(-0.30)\end{array}$ \\
\hline Trading fund status (dummy) & $\begin{array}{c}1.11 \\
(0.24)\end{array}$ & $\begin{array}{c}1.50 \\
(1.23)\end{array}$ & $\begin{array}{l}0.32 * * \\
(-2.30)\end{array}$ \\
\hline $\begin{array}{l}\% \text { of all targets last year that cover } \\
\text { outcomes or efficiency }\end{array}$ & $\begin{array}{c}0.98 \\
(-1.26)\end{array}$ & $\begin{array}{c}1.00 \\
(-0.14)\end{array}$ & $\begin{array}{c}0.98 \\
(-1.28)\end{array}$ \\
\hline Number of targets last year & $\begin{array}{l}1.03 * \\
(1.81)\end{array}$ & $\begin{array}{c}1.01 \\
(0.46)\end{array}$ & $\begin{array}{l}0.93 * * \\
(-2.31)\end{array}$ \\
\hline Media stories last year Z-score & $\begin{array}{c}1.06 \\
(0.39)\end{array}$ & $\begin{array}{c}0.95 \\
(-0.34)\end{array}$ & $\begin{array}{c}0.78 \\
(-1.38)\end{array}$ \\
\hline Media stories this year Z-score & $\begin{array}{c}0.87 \\
(-0.82)\end{array}$ & $\begin{array}{c}1.12 \\
(0.78)\end{array}$ & $\begin{array}{l}1.16 \\
(1.11)\end{array}$ \\
\hline Agency head spells & 247 & 247 & 247 \\
\hline $\begin{array}{l}\text { Agency head tenure endings by } \\
\text { exit type (in total, there are } 142 \text { endings) }\end{array}$ & 39 & 43 & 60 \\
\hline Observations & 934 & 934 & 934 \\
\hline Log pseudo-likelihood & -181.14 & -193.69 & -220.73 \\
\hline
\end{tabular}

We report hazard ratios (exponentiated coefficient estimates). A hazard ratio greater than one indicates that an explanatory variable is associated with a shorter time until an exit from the agency head position. We report robust $\mathrm{z}$-statistics in parentheses below the hazard ratios $(* * * \mathrm{p}<0.01, * * \mathrm{p}<0.05, * \mathrm{p}<0.1)$. 
Figure 1: Chief executive tenure survivor function

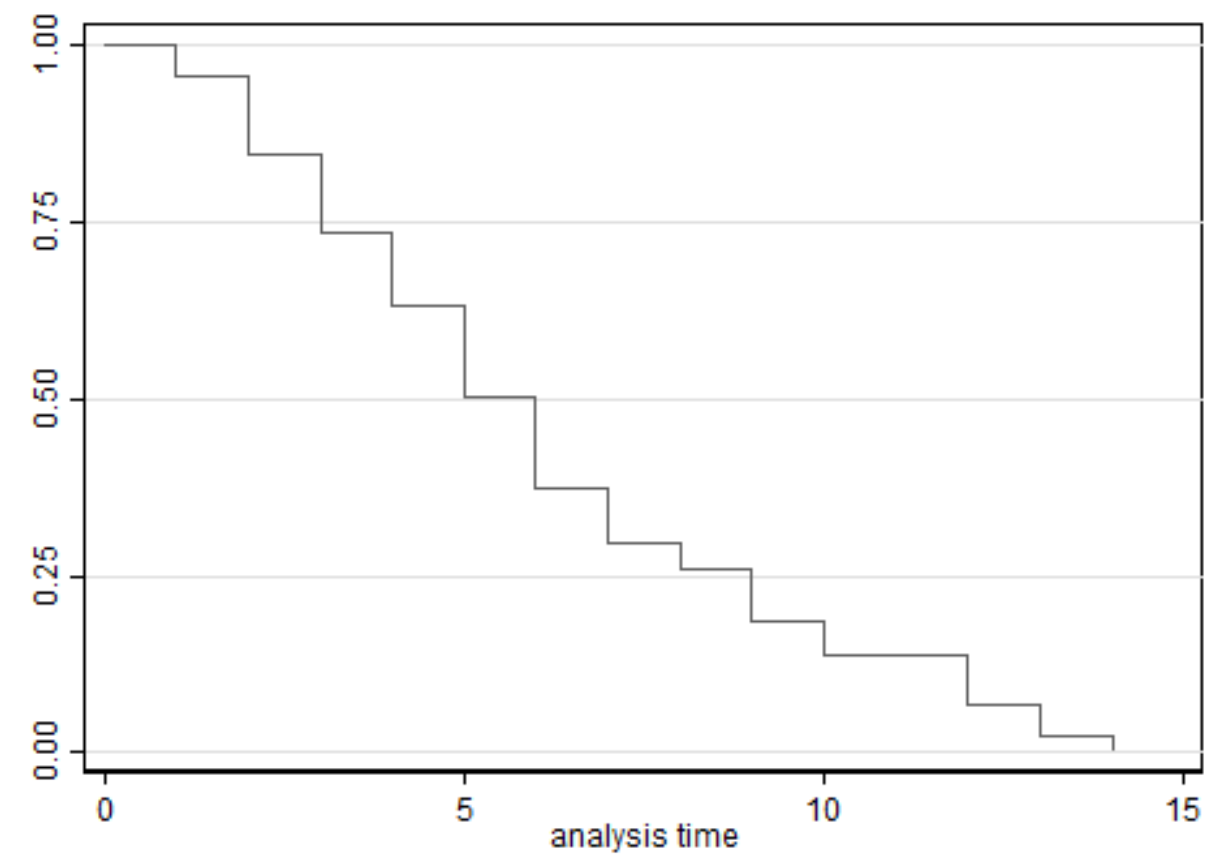


Figure 2: Chief executive tenure length by exit type

Exit into public sector

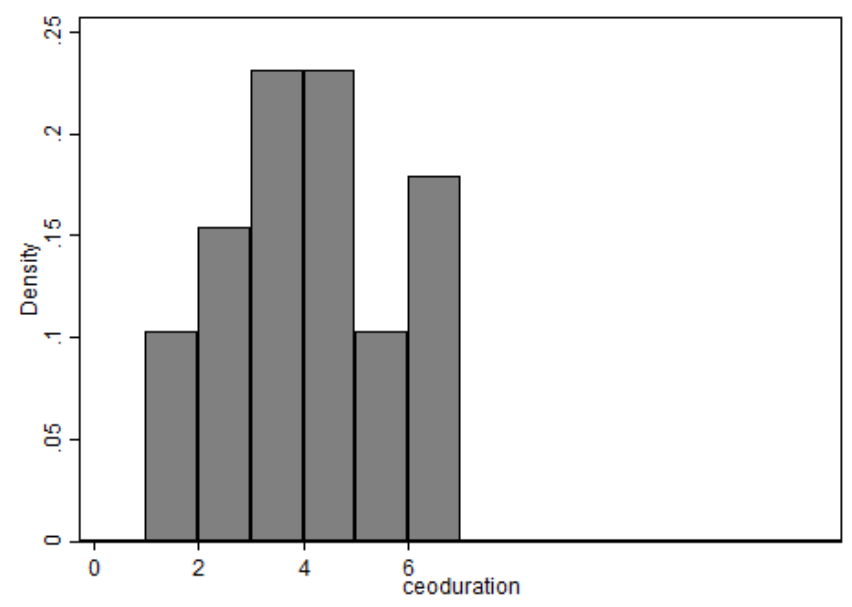

Exit into private \& nonprofit sector

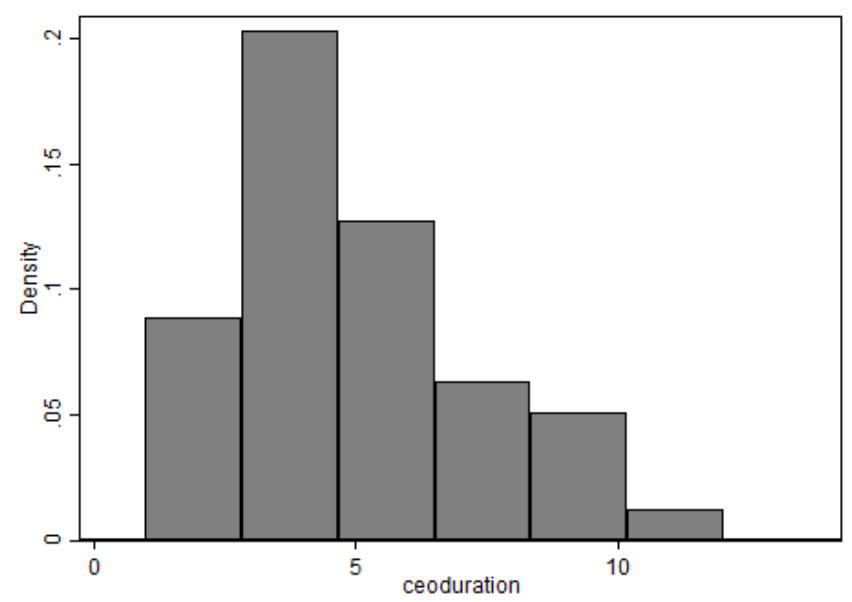

Exit into formal retirement

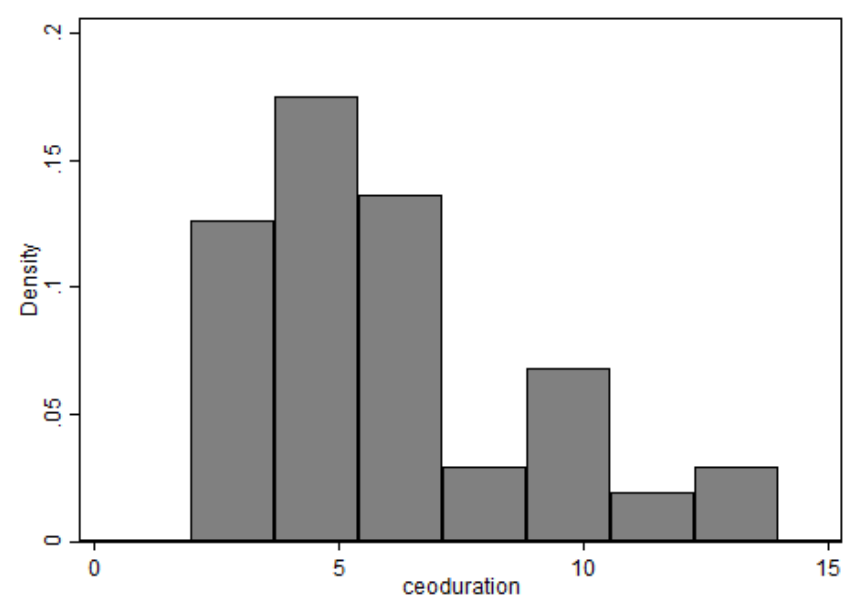

